\title{
EMPIRE FORESTRY REVIEW
}

Vol. 27, No. 1, 1948, of the Empire Forestry Review published by the Empire Forestry Association and edited by H. R. Blandford, O.B.E., is to hand. As usual there is a wide range of articles and reviews, together with research notes and numerous editorial notes of interest. Among others should be mentioned the articles "Working Plans of the Swedish State Forests" by Nils Smith; "Proposed Sustained-Yield Units for British Columbia" by J. D. Gilmour; and "Note on Sand Dune Fixation in Palestine" by G. N. Sale.

Reviews of the Report of the Ontario Royal Commission on Forestry by J. A. Brodie, and the Report of the Saskatchewan Royal Commission on Forestry by J. D. B. Harrison, also a review by Barrington Moore of J. O. Wilson's article, "Implementing the Forest Policy" will be of special interest to Canadian foresters.

This review is a valuable reference and a great deal of pertinent and up. to-the-minute information requiring considerable editorial effort to assemble is to be found between its covers.

\section{NEWS BULLETIN OF EMPIRE FOREST DEPARTMENTS}

A complimentary copy of the 1947 issue of the above publication has just been received. In future this bulletin will appear as the News Bulletin of Commonwealth Forest Departments, and F. C. Ford Robertson, Director of the Commonwealth Forestry Bureau, New Bodleian Building, Oxford, England, expresses the wish that more foresters in Canada will enter their names as permanent subscribers. (Price five shillings annually).

This bulletin provides an informative summary of the work of all Commonwealth forest departments which no forester should be without, and we heartily endorse Mr. Robertson's suggestion that fellowship among foresters of the Commonwealth would be promoted by a sharing of readership interest in this useful publication.

\section{WOODLAND WORLD}

Volume 1 Number 1 of the Woodland World made its bow to the Canadian public in June.

It is published by the Canadian Forestry Association for the purpose of encouraging the intelligent management of woods, waters, wildlife and soils. The present circulation is 18,000 , and plans are being made to increase this to 25,000 by the end of 1948 and 50,000 by the end of 1949 .

The present format is eight pages of small sized newsprint with plenty of photographs. By judicious arrangement and use of different type faces the news is presented in such a way that it is easy to read. It is most important in a publication of this nature that the contents should have human interest appeal. The Woodlands Review qualifies in this respect, and we wish it a long and lusty life in the essential but often neglected field of popularizing forestry and conservation in Canada. 